\title{
ALIRAN PEMIKIRAN EKONOMI ISLAM KONTEMPORER
}

\section{Nur Asia/ 90100118093}

\section{Email: ochiena98@ gmail.com}

Pada awal dekade 1980-an, terjadi beberapa perbedaan pendapat diantara para pakar ekonomi Islam mengenai interpretasi atas istilah-istilah dan konsepkonsep tertentu dalam al-Qur'an dan as-Sunnah. Dan berbagai perbedaan lainnya. Namun demikian, hakekat pada permasalahan perbedaan tersebut, sesungguhnya para pemikir ekonomi Islam pada masa kontemporer sepakat akan hal filosofifilosofi dasar syari'ah Islam yaitu dengan berbasis pada al-Qur'an dan as-Sunnah (Santoso, 2016).

Pemikiran ekonomi Islam muncul bersamaan dengan diturunkannya AlQur'an dan masa kehidupan Rasulullah yakni pada akhir abad $6 \mathrm{M}$ hingga awal abad 7 M. Pelaksanaan sistem ekonomi Islam telah ada dan dilaksanakan oleh Rasulullah SAW sebagai seorang Rasul tauladan bagiumat muslim. Bahkan bangsa Arab telah terkenal sebagai bangsa pedagang sebelum periode Rasulullah SAW (Fauzi, et al., 2019). Namun Kemudian barulah mulai didokumentasikan kurang lebih sejak tiga abad semenjak wafatnya Nabi Muhammad Saw. Beberapa pemikir yang cukup terkenal antara lain : Abu Yusuf (731-798), Yahya ibn Adham (818), El-Hariri (1054-1122), Tusi (1201-1274), Ibn Taimiyah (12621328), Ibn Khaldun (1332-1406) dan Shah Waliullah (1702-1763) (Khoir, 2010). Pemikiran-pemikiran dari cendekia-wan muslim tentang ekonomi islam ini sempat berhenti beberapa abad lamanya. Pertengahan abad ke-20 M pemikiran ekonomi Islam berkembang kembali (Nurrohman \& Nurhaeti, 2019). Dengan muncul pemikir-pemikir ekonomi kontemporer yang dapat dikategorikan dalam tiga kelompok mazhab pemikiran yaitu (Maulidizen, 2017)

1) Mazhab Baqir As-Sadr

Pada aliran ini pemikiran tentang pemecahan masalah ekonomi yang muncul disebabkan distribusi yang tidak merata dan adil sebagai pengaruh dari ekonomi kapitalis yang menguntungkan pihak yang kuat dan kaya sehingga terjadilah ketimpangan sosial menyebabkan maraknya kasus eksploitasi, 
diskriminasi, monopoli, dan alienasi. Perebutan kepemilikan harta kekayaan alam terus berlangsung berkecamuk disegalah lini yang berujung pada kriminalitas dan konflik sosial, yang sangat sulit untuk dihindari (Sirajuddin \& Tamsir, 2019).

Pemahaman ekonomi iqtisaduna beranggapan bahwa puncak permasalahan ekonomi adalah bukan karena sumber daya yang tidak terbatas, tetapi karena ketamakan manusia yang tidak terbatas. Faham mazhab ekonomi ini menganggap bahwa segala sumber daya alam adalah tidak terbatas. Aliran ini dipelopori oleh Baqir Sadr. Membahas mengenai permintaan dan penawaran, hubungan antara keuntungan dan bunga, juga fenomena diminishing return dalam suatu produksi.

2) Mazhab Mainstream

Sebagai kebalikan dari aliran iqtisaduna. Mazhab ini Pmengemukakan bahwa permasalahan ekonomi, menurut mereka masalah ekonomi dikarenakan kekurangan (scarcity). Ini maksudnya segala sumber daya alam adalah terbatas tetapi keperluan manusia yang tidak terbatas. Untuk itu manusia diarahkan untuk melalukan aktivitas ekonomi berdasarkan kepada skala prioritas dalam memenuhi kebutuhan manusia dengan tetap berpegang teguh kepada al-Qurean dan al- Hadist. Tokoh-tokoh utama pada aliran ini iaitu, Muhammad abdul Mannan, Muhammad Nejatullah Siddiqi, Syed Nawab Haidar Naqvi, dan Monzer Kahf.

3) Mazhab Alternatif

Aliran ini adalah aliran kritis secara ilmiah terhadap ekonomi Islam, baik sebagai ilmu maupun sebagai peradaban. Aliran ini mengkritik kedua aliran kontemporer sebelumnya. Aliran Iqtiṣādunā dikritik karena dianggap berusaha mengemukakan sesuatu yang baru yang sebenarnya sudah ditemukan oleh tokohtokoh klasik sebelumnya, sedangkan aliran mainstream dikritik sebagai aliran serapan dari neo-klasik tetapi mengahapuskan elemen ribā serta menambah zakat dan akad, sehingga tidak ada keaslian pada aliran ini. Tokoh aliran ini adalah Timur Kuran.

Diyakini bahwa Islam pasti benar, tetapi ekonomi Islam sebagai sebuah tafsir terhadap ajaran Islam belum tentu benar, dan seandainya benar maka 
kebenaran itu tidak bersifat mutlak. Semua proposisi kebenaran yang diajukan oleh ekonomi Islam juga harus diuji kebenarannya sebagaimana proposisi konvensional. Maka semua hasil dari uji kebenaran ini merupakan sebuah tradisi ilmiah yang akan menguji sejauh mana tingkat validitas dari sebuah konsep ekonomi Islam. (Abidin, 2015)

Pada dasarnya dari ketiga mazhab tersebut, masing-masing mempunyai kelebihan dan kelemahan, di samping ada kesamaan dan perbedaan. Di antara persamaan dari mazhab-mazhab tersebut adalah mengenai dasar-dasar filosofi dari sistem ekonomi Islam. Seperti tauhid, khilafah, ibadah, takaful dan 'adalah. Di samping mereka juga sepakat terhadap sumber hukum yaitu Al-Qur'an dan As- Sunnah, serta prinsip-prinsip umum yang dijelaskan keduanya seperti kewajiban zakat dan pelarangan riba sebagai dasar dari sistem ekonomi Islam (Aravik, 2017 , p. 12) 


\section{DAFTAR PUSTAKA}

Helim, A., \& Fauzi, I. (2019). Sejarah pemikiran ekonomi islam (Masa Rasulullah sampai masa kontemporer).

Khoir, M. (2010). Pemikiran Dan Mazhab Ekonomi Islam Kontemporer. BALANCE: Economic, Business, Management and Accounting Journal, 7(01).

Maulidizen, A. (2017). Pemikiran Dan Kontribusi Tokoh Ekonomi Islam Klasik Dan Kontemporer. deliberatif, 1(1), 42-62.

Nurohman, N. (2019). Pemikiran Ekonomi Mikro Islam Dalam Lintasan Sejarah. Aksy: Jurnal Ilmu Akuntansi dan Bisnis Syariah, 1(2), 225232.

Sirajuddin, S., \& Tamsir, T. (2019). Rekonstruksi Konseptual Kepemilikan Harta Perspektif Ekonomi Islam (Studi Kritis Kepemilikan Harta Sistem Ekonomi Kapitalisme). Laa Maisyir: Jurnal Ekonomi Islam, $6(2), 211-225$.

Aravik, H. (2017). Sejarah Pemikiran Ekonomi Islam Kontemporer. Kencana.

Santoso, S. (2016). Sejarah Ekonomi Islam Masa Kontemporer. AnNisbah: Jurnal Ekonomi Syariah, 3(1), 60-86. 